\title{
Correction to: M2 Macrophagy-derived exosomal miRNA-5106 induces bone mesenchymal stem cells towards osteoblastic fate by targeting salt-inducible kinase 2 and 3
}

Yuan Xiong ${ }^{1 \dagger}$, Lang Chen ${ }^{1 \dagger}$, Chenchen Yan ${ }^{1 \dagger}$, Wu Zhou', Tao Yu², Yun Sun ${ }^{3}$, Faqi Cao ${ }^{1}$, Hang Xue ${ }^{1}$, Yiqiang Hu', Dong Chen ${ }^{1}$, Bobin $\mathrm{Mi}^{{ }^{* *}}$ and Guohui Liu ${ }^{1 *}$ (D)

\section{Correction to: J Nanobiotechnol (2020) 18:66}

https://doi.org/10.1186/s12951-020-00622-5

Following publication of the original article [1], the authors reported that Fig. 2 was not updated during the production process.
The updated Fig. 2 is provided below and the original article [1] has been corrected.

*Correspondence: mibobin@hust.edu.cn; liuguohui@hust.edu.cn

${ }^{\dagger}$ Yuan Xiong, Lang Chen, and Chenchen Yan contributed equally to this work

1 Department of Orthopaedics, Union Hospital, Tongji Medical College, Huazhong University of Science and Technology, Wuhan 430022, China

Full list of author information is available at the end of the article

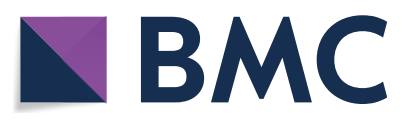

(c) The Author(s) 2021. This article is licensed under a Creative Commons Attribution 4.0 International License, which permits use, sharing, adaptation, distribution and reproduction in any medium or format, as long as you give appropriate credit to the original author(s) and the source, provide a link to the Creative Commons licence, and indicate if changes were made. The images or other third party material in this article are included in the article's Creative Commons licence, unless indicated otherwise in a credit line to the material. If material is not included in the article's Creative Commons licence and your intended use is not permitted by statutory regulation or exceeds the permitted use, you will need to obtain permission directly from the copyright holder. To view a copy of this licence, visit http://creativecommons.org/licenses/by/4.0/. The Creative Commons Public Domain Dedication waiver (http://creativecommons.org/publicdomain/zero/1.0/) applies to the data made available in this article, unless otherwise stated in a credit line to the data. 

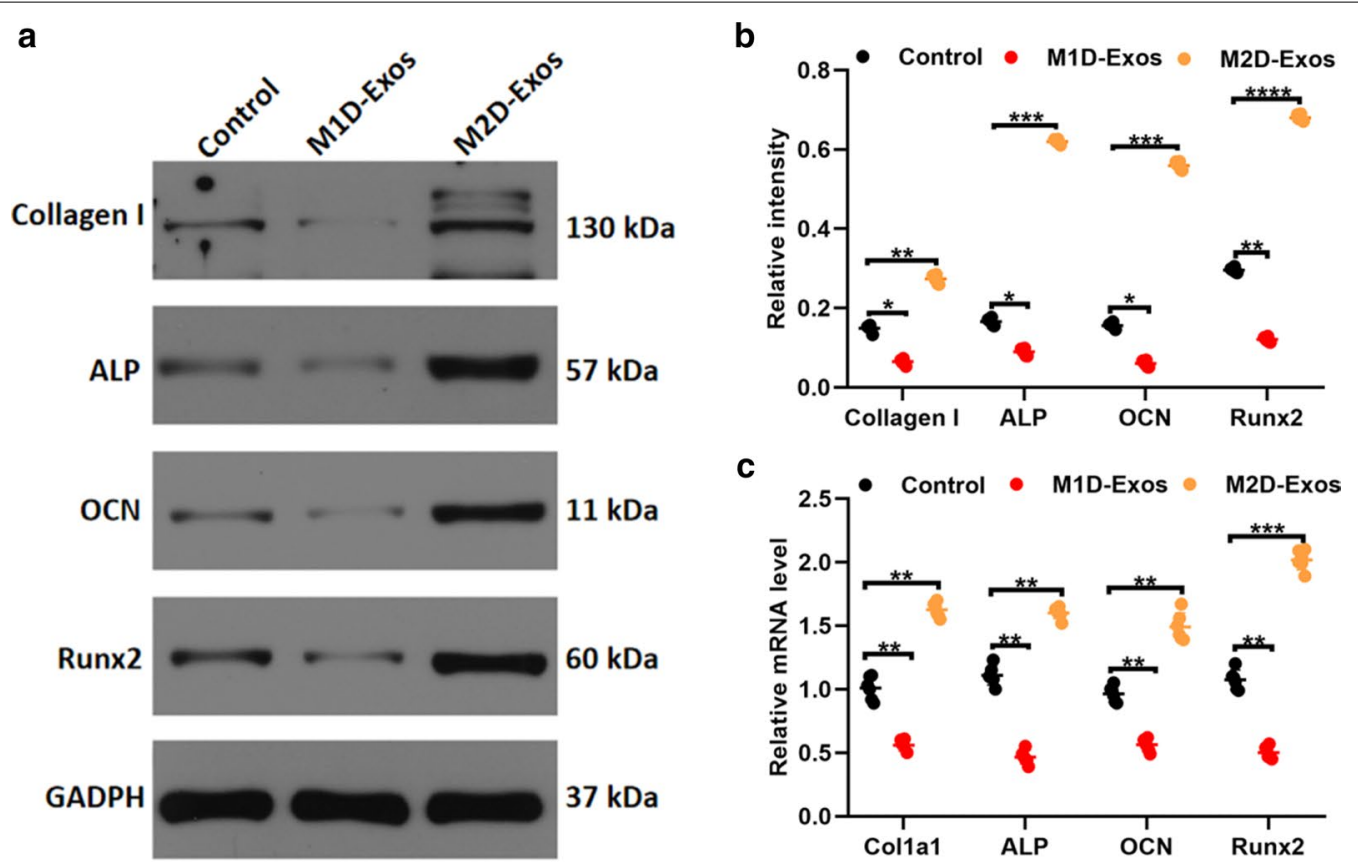

d
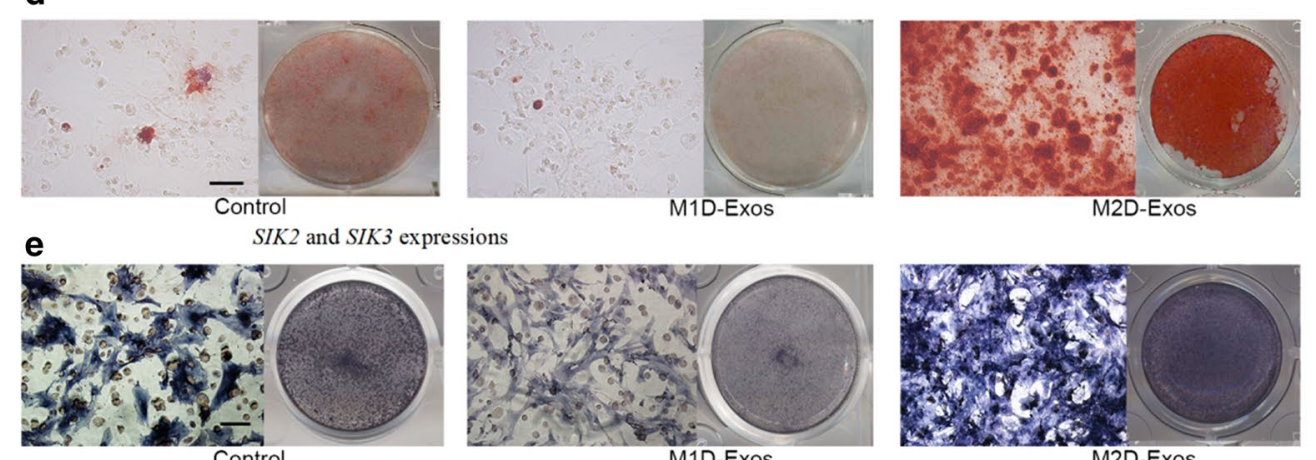

f
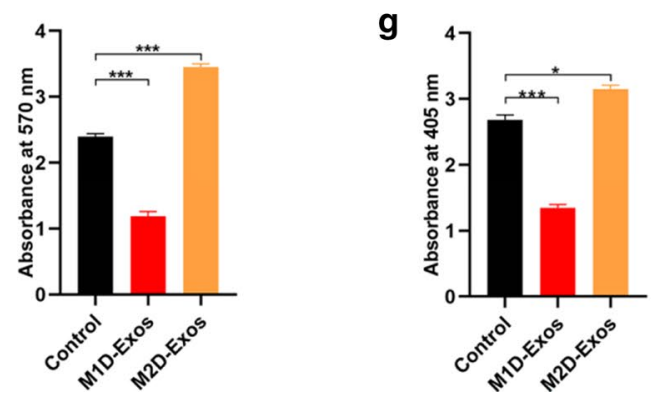

Fig. 2 M2D-Exos induce osteoblast activity and matrix mineralization. a Osteogenic genes were upregulated in M2D-Exos-treated BMSCs measured by western blotting analysis; $\mathbf{b}$ The relative intensity of western blotting analysis; $\mathbf{c}$ Overexpression of the four osteognic genes can be detected in M2D-Exos groups measured by qRT-PCR analysis; $\mathbf{d}$ Alizarin red-mediated calcium staining in BMSCs following treated by PBS (control group), M1D-Exos, and M2D-Exos for 21 days. Scale bar = $10 \mathrm{~mm}$; e ALP staining in BMSCs following treated by PBS (control group), M1D-ExOs, and M2D-Exos for 14 days. Scale bar $=10 \mathrm{~mm} ; \mathbf{f}, \mathbf{g}$ The statistical data of Alizarin red-mediated calcium staining and ALP staining. Data are mean \pm SD of triplicate experiments. ${ }^{*} p<0.001,{ }^{* *} p<0.01,{ }^{* * *} p<0.001$

\section{Author details}

${ }^{1}$ Department of Orthopaedics, Union Hospital, Tongji Medical College, Huazhong University of Science and Technology, Wuhan 430022, China. ${ }^{2}$ Department of Orthopedic Surgery, Tongji Hospital, Tongji University School of Medicine, Shanghai 200065, China. ${ }^{3}$ Department of Neurosurgery, Union
Hospital, Tongji Medical College, Huazhong University of Science and Technology, Wuhan 430022, China.

Published online: 27 March 2021 


\section{Reference}

1. Xiong Y, Chen L, Yan C, Zhou W, Yu T, Sun Y, Cao F, Xue H, Hu Y, Chen D, Mi B, Liu G. M2 Macrophagy-derived exosomal miRNA-5106 induces bone mesenchymal stem cells towards osteoblastic fate by targeting salt-inducible kinase 2 and 3. J Nanobiotechnol. 2020;18:66. https://doi. org/10.1186/s12951-020-00622-5.
Publisher's Note

Springer Nature remains neutral with regard to jurisdictional claims in published maps and institutional affiliations.
Ready to submit your research? Choose BMC and benefit from:

- fast, convenient online submission

- thorough peer review by experienced researchers in your field

- rapid publication on acceptance

- support for research data, including large and complex data types

- gold Open Access which fosters wider collaboration and increased citations

- maximum visibility for your research: over $100 \mathrm{M}$ website views per year

At BMC, research is always in progress.

Learn more biomedcentral.com/submissions 